\title{
Empresas transnacionais (ETNs) e os países pobres: reflexões sobre a governança global
}

Cláudia Andreoli Galvão** Violeta de Faria Pereira**

\section{Resumo}

As transnacionais incorporam áreas de países pobres enquanto não existirem oportunidades de exploração em outros países, transferem esses investimentos de país a país, territorializando e desterritorializando países e regiões, alterando a conformação espacial do mundo, criando e expandindo a desigualdade entre, principalmente, os países mais podres. As transnacionais poderiam ser controladas por instâncias reguladoras globais, regionais, nacionais ou locais, mais presentes e efetivas atenuando os efeitos negativos do processo de avanço do capitalismo no mundo. Nesse sentido, o presente estudo analisou, através de revisão bibliográfica, a alternativa de existência das instâncias reguladoras para conter os efeitos nefastos do processo de avanço das transnacionais nos países hospedeiros. Para tanto foi necessário aprofundar o conhecimento da nova configuração do capitalismo e de suas consequências para os países mais pobres, bem como analisar como as práticas espaciais das empresas transnacionais levaram à fragmentação do processo produtivo em escala global, incorporando regiões e países, mas de forma não homogênea, ainda que algumas das razões da diferenciação do processo de incorporação de espaços pelas corporações transnacionais sejam bastante conhecidas, resultado que

* Ph. D em Economia, University of Sheffield, Reino Unido. Professora Colaboradora do Departamento de Geografia, Universidade de Brasília (claudiaandreoli@gmail.com).

** Professora do Departamento de Geografia, Universidade de Brasília (violeta@unb.br).

Geosul, Florianópolis, v. 32, n. 63, p 7-48, jan./abr. 2017 
GALVÃO, C.A. \& PEREIRA, V.F. Empresas transnacionais (ETNs) e os ...

são do avanço nas comunicações, bem como das facilidades de uma base científica desenvolvida pela disponibilidade de centros de pesquisa nos países hospedeiros, ademais da vantagem de mão de obra mais barata, e das facilidades oferecidas pelos governos locais.

Palavras-chave: Reconfiguração do capitalismo; Empresas transnacionais; Práticas espaciais das transnacionais; Instâncias reguladoras; Governança global.

Transnational corporations (TNCs) and poor countries: reflections on global governance

\section{Abstract}

Transnational corporations (TNCs) incorporate areas of poor countries while there are no exploring opportunities in other countries, they transfer their investments from country to country, territorializing / deterritorializing countries and regions, changing the spatial configuration of the world, creating and expanding inequality between, mainly, poorer countries. TNCs could be controlled by global, regional, national or local regulatory bodies more present and effective, mitigating the negative effects of the advancement of capitalism in the world. In this sense, this study analyzed, through literature review, the alternative of existence of regulatory bodies to contain the adverse effects of the process of advancement of transnationals corporations in host countries. Therefore, it was necessary to deepen the knowledge of the new configuration of capitalism and its consequences for the poorest countries, as well, to analyze the spatial practices of transnational corporations that led to the fragmentation of the production process on a global scale, incorporating regions and countries, but not in a homogeneous form, although some of the reasons for the differentiation of the process of incorporation of spaces by transnational corporations be well known, as they are the result of the advancement in communications, as well as the facilities of a scientific base developed by the availability of 
GALVÃO, C.A. \& PEREIRA, V.F. Empresas transnacionais (ETNs) e os ...

research facilities in host countries, besides the advantage cheaper labor, and the facilities offered by local governments.

Key words: Reconfiguration of capitalism; Transnational corporations; Spatial practices of transnational corporations; Regulatory bodies; Global governance.

\section{Introdução}

O capitalismo se reconfigurou a partir dos anos 70 utilizando a estratégia de fragmentar a produção em várias partes do mundo de forma a minimizar os custos, valendo-se do fato de que diversos segmentos do processo produtivo que utiliza mais trabalho intensivo não qualificado pode ser deslocado para países periféricos, nos quais esse fator é abundante e barato, assim sendo as empresas transnacionais $(\mathrm{ETN})^{1}$ adotam estratégias globais de forma a se beneficiarem das vantagens de uma rede criadora de valor além das próprias fronteiras. $\mathrm{O}$ resultado para os países periféricos é desdobrado em saldos positivos entre destruição e criação de postos de trabalho para as áreas geográficas mundiais com maiores vantagens comparativas, enquanto outros países com menores vantagens comparativas acabam à margem da integração ao sistema econômico mundial. Assim, o fato incontestável é que a divisão internacional do trabalho é desigual no mundo. Enquanto os países de industrialização tardia, os ditos Newly Industrialized Countries, tiveram uma parte de sua população com padrão de vida similar ao dos países capitalistas centrais, a periferia não só não consegue manter esse padrão, como perde inclusive participação no fluxo de recursos internacionais.

${ }^{1}$ Utilizaremos aqui a definição de Empresas Transnacionais introduzida por Dicken (2010, p. 37), definição essa que ele considera mais ampla por ir além da definição convencional baseada nos níveis de propriedade de ativos com base internacional, abrangendo, desta maneira, a diversidade e a complexidade das redes transnacionais: "Uma empresa transnacional é uma empresa que tem o poder para coordenar e controlar operações em mais de um país, mesmo que não sejam de propriedade dessa empresa." 
GALVÃO, C.A. \& PEREIRA, V.F. Empresas transnacionais (ETNs) e os ...

A era da globalização tem sido marcada por grandes avanços tecnológicos, melhorias comerciais e o aumento de investimento. No entanto, a evolução dos indicadores de desenvolvimento humano tem sido desigual entre as regiões e entre dimensões diferentes. Os processos contemporâneos da globalização foram acompanhados por um aumento na desigualdade e vulnerabilidade globais. De acordo com Dicken (2010, p. 471) 20\% da população mundial vivendo nos países de mais alta renda controlam mais de $80 \%$ da renda, do comércio, investimento e da tecnologia de comunicação mundial, enquanto os $20 \%$ da população mundial que vivem nos países pobres controlavam $1 \%$ desses mesmos fluxos. Os países desenvolvidos têm mantido ou aumentado sua riqueza, e alguns países em desenvolvimento fizeram progressos importantes, mas existe um núcleo de países que permanecem estagnados. $\mathrm{O}$ crescimento econômico mundial não beneficiou a todos, e em especial não incluiu nos seus benefícios os países da África subsaariana e partes do Sul da Ásia.

O objetivo do presente estudo é analisar a alternativa de existência de instâncias reguladoras nacionais e supranacionais para conter os efeitos nefastos do processo de avanço das transnacionais nos países hospedeiros. Nesse sentido, precisamos aprofundar o conhecimento do processo de avanço das corporações transnacionais que levou à fragmentação do processo produtivo em escala global, incorporando regiões e países, mas de forma não homogênea, ainda que algumas das razões da diferenciação do processo de incorporação de espaços sejam bastante conhecidas, resultado que são do avanço nos transportes e nas comunicações, bem como das facilidades de uma base científica suficientemente desenvolvida pela disponibilidade de centros de pesquisa e desenvolvimento e de universidades nos países hospedeiros, ademais da clássica vantagem de mão de obra mais barata, e das facilidades oferecidas pelos governos locais.

Além dessa Introdução o trabalho se compõe dos seguintes itens: 1) Nova configuração do capitalismo; 2) Práticas espaciais das corporações transnacionais; 3) Consequências da reconfiguração do 
GALVÃO, C.A. \& PEREIRA, V.F. Empresas transnacionais (ETNs) e os ...

capitalismo para os países periféricos; 4) A governança global e o papel do Estado e finaliza com as Considerações finais.

\section{Nova configuração do capitalismo}

A partir dos anos 70, a produção passou a ser fragmentada internacionalmente com o objetivo de minimizar os custos totais, assim os segmentos dos processos produtivos que utilizam mais trabalho intensivo não qualificado têm sido deslocados para países nos quais esse fator é abundante e barato, os países da periferia. Nesse novo paradigma que configura o capitalismo global o que se observa é uma intensificação das redes globais apoiadas no desenvolvimento dos transportes e das telecomunicações, na evolução da tecnologia de informação, que permite, conforme apontado por Dupas (2001), a fragmentação e padronização de tarefas específicas levando à utilização de grandes estoques de reserva de baixos salários em países periféricos. Certamente o aumento da pressão sindical por salários mais altos e melhores condições de trabalho nas economias desenvolvidas foi um dos fatores determinantes adicionais para levar as empresas transnacionais a deslocar partes ou todo o processo produtivo para países em desenvolvimento.

Ferrer (1998, apud DUPAS, 2001) mostra que, a partir dos anos 80 , um novo padrão de acumulação se faz presente nos países centrais utilizando capital intensivo em substituição ao trabalho intensivo, como consequência diminui a força dos sindicatos e o desemprego estrutural passa a funcionar como disciplinador da força de trabalho, assim, declina o poder de barganha dos assalariados.

Para Storper (1994) a internacionalização tem aumentado o investimento estrangeiro, assim como aumentou as quantidades de parcerias e alianças entre grandes empresas e o volume do comércio intraindustrial.

Às tendências citadas deve-se acrescentar a relativa facilidade que as empresas transnacionais adquiriram recentemente em 
GALVÃO, C.A. \& PEREIRA, V.F. Empresas transnacionais (ETNs) e os ...

transferir o local de sua produção de acordo com as conveniências de custos, benefícios fiscais, políticas industriais e comerciais. Esse fato pode gerar profundas e funestas consequências nos países periféricos, que ficam à mercê da escalada mundial das multinacionais em busca de manter seu padrão de acumulação extremamente elevado. De fato, mesmo depois de instaladas, elas costumam manter razoável poder de barganha e capacidade relativa de distribuir a produção entre outras indústrias. Stiglitz (2006) argumenta que além de poder econômico elas detêm poder político e de barganha para evitar regulação e impostos, uma vez que podem se transferir para outros países. Esse autor acrescenta que com a intenção de reduzir custos algumas ETNs evitam pagar impostos, limitam os planos de saúde de seus trabalhadores e reduzem gastos na contenção da poluição - muitas vezes esses custos ficam a cargo dos governos de países nos quais elas operam.

Dupas (2001) discute como a tecnologia vem influenciando as cadeias produtivas e a geração de empregos nos países ricos e pobres. Os grandes avanços tecnológicos nos meios de comunicação e transporte permitem uma considerável fragmentação no processo de produção e consequentemente uma crescente flexibilização da mão de obra.

As transnacionais geram mais empregos diretos e formais nas sedes e em países em desenvolvimento do que em países pobres. Dupas (2001) explica as diferenças dessas mudanças nas cadeias produtivas nos países pobres e ricos e discorre sobre como esse processo se deu. Nos anos 70 começou um processo de desindustrialização nos países ricos ocasionado também, além do desenvolvimento tecnológico e outros fatores macroeconômicos, pela dificuldade desses países em manter o nível dos empregos industriais, ocorrendo, dessa maneira, um deslocamento das cadeias globais para a periferia. Nos países centrais observou-se a diminuição de postos de trabalho na indústria prejudicando trabalhadores menos qualificados, no entanto, a periferia foi beneficiada por esse deslocamento. Nessa nova fase, os países emergentes são colocados como provedores de mão de obra de pouca qualificação a baixos custos. Embora a 
GALVÃO, C.A. \& PEREIRA, V.F. Empresas transnacionais (ETNs) e os ...

qualidade dos empregos gerados na periferia seja de qualidade inferior aos empregos gerados nos países sede, não se pode deixar de destacar que são melhor remunerados que os empregos oferecidos nos países pobres. Ainda que não seja possível atribuir números exatos aos empregos obtidos e perdidos através do investimento direto estrangeiro, um aspecto está bem claro: os vencedores e os perdedores raramente são os mesmos.

Dicken (2010) ressalta que os países mais pobres do mundo não atraem altos níveis de investimentos direto estrangeiro (IDE), e que em alguns casos, sequer o atraem. Esse autor também ressalta que um vasto volume de investimento direto estrangeiro mundial é direcionado para as economias desenvolvidas, enquanto a parte destinada aos países em desenvolvimento está concentrada em um pequeno número de países recém-industrializados. Esse autor acrescenta que os países mais pobres também não atraem muito investimento em portfolio porque há poucas oportunidades atrativas de investimento em suas economias domésticas, sendo que, para os países mais pobres, o grande fluxo externo de renda ocorre através de programas de incentivo. No entanto, segue o autor, esses fluxos estão não somente muito aquém dos níveis necessários, como também estão diminuindo.

Para Ascani, Crescenzi e Immarino (2012) a globalização tem contribuído para a evolução progressiva do paradigma da organização industrial da produção em massa para sistemas de produção mais flexíveis e bem sucedidos, como uma maneira de responder à pressão da concorrência crescente dos mercados internacionais. Como resultado, acrescentam esses autores, a produção estandartizada tornou-se progressivamente obsoleta em favor de um sistema especializado e mais flexível a mudanças na demanda, o que permitiu às empresas sobreviver à incerteza dos desafios globais. Pari passo a essas mudanças, a importância das empresas transnacionais aumentou e contribuiu ainda mais para o enfraquecimento das fronteiras nacionais e das instituições econômicas na gestão do desenvolvimento econômico regional. 
GALVÃO, C.A. \& PEREIRA, V.F. Empresas transnacionais (ETNs) e os ...

A era da globalização embora marcada por grandes avanços tecnológicos, melhorias comerciais e aumento de investimento não conseguiu apresentar uma evolução dos indicadores de desenvolvimento humano equilibrada no mundo, e mais, os processos contemporâneos da globalização foram acompanhados por um aumento na desigualdade e vulnerabilidade globais.

Os países desenvolvidos têm mantido ou aumentado sua riqueza, e alguns países em desenvolvimento fizeram progressos importantes, mas existe um núcleo de países que permanecem estagnados. O que é fato é que o crescimento econômico mundial não beneficiou a todos, sendo que os países da África subsaariana e partes do Sul da Ásia foram os que menos se beneficiaram.

Ainda discutindo a questão do emprego, Dupas (2001) nos mostra que as empresas líderes das cadeias mundiais e seus fornecedores globais geram menos empregos diretos e formais por dólar adicional investido. Ainda segundo o autor (DUPAS, 2001) isso se deve a fatores associados à automação e à informatização crescente dos sistemas de gestão e produção e aos radicais processos de reengenharia e down sizing, inevitavelmente associados à busca de concentração na ponta superior das cadeias. Algumas estratégias adotadas pelas corporações que parecem ter contribuído para a queda de emprego por dólar investido são: aceleração da integração das cadeias internacionais de produção; aplicação de tecnologias modernas a processos tradicionais; adoção de técnicas de lean production; e intensificação de acordos de outsourcing intrafirmas e de subcontratação, com queda do emprego direto e crescimento do indireto.

As cadeias globais têm em seu topo intensa concentração de empresas líderes, compostas por corporações líderes e fornecedores globais de alta qualificação, formadas a partir da fusão, aquisição, join ventures e acordos tecnológicos, que exigem contrato formal de trabalho. Por outro lado, na base da cadeia o que ocorre é a fragmentação através de franquias, subcontratações e parcerias caracterizadas por serem de processo bem mais flexível e informal que os empregos do topo da cadeia. 
GALVÃO, C.A. \& PEREIRA, V.F. Empresas transnacionais (ETNs) e os ...

A cadeia produtiva global seleciona pessoas qualificadas para ocuparem o emprego formal e inclui na base os trabalhos oferecidos com baixos salários e de contratação flexível, inclusive o trabalho informal. Dupas (2001) afirma que as cadeias globais produtivas são responsáveis por uma nova dinâmica mundial em que tecnologia e acesso à informação são fundamentais para estabelecer os locais mais bem sucedidos nos processos de produção e inserção no mercado, em todos os níveis.

$\mathrm{Na}$ análise das consequências sobre o emprego, Dupas (2001) torna claro que devem ser computados os empregos gerados pela implantação da filial e seus efeitos multiplicadores sobre outros setores. No entanto deve-se também quantificar os impactos negativos, ou seja, quantos postos de trabalho foram destruídos por esse investimento, quais as quebras provocadas em empresas locais e que outras empresas iriam ser implantadas e deixaram de sê-lo pelo fato daquele investimento ter sido realizado.

O impacto da internacionalização das cadeias produtivas sobre os países de origem é complexo. Primeiramente, deveriam ser analisados os efeitos no emprego considerando se os investimentos tivessem sido feitos nos países centrais e não nos países hospedeiros. Em segundo lugar, seria possível questionar se as empresas nos países centrais teriam conseguido sobreviver sem se internacionalizarem, uma vez que assim o fazendo incorporam custos menores viabilizando o empreendimento como um todo.

Dupas (2001) em sua obra apresenta estimativas de que para cada emprego direto criado pelas corporações, é gerada uma quantidade muito maior de empregos, principalmente por meio de suas compras de matérias-primas, componentes, serviços de subcontratados e fornecedores externos, inclusive pelos elos existentes entre as empresas transnacionais e os distribuidores do produto final. A geração de empregos diretos tem crescido junto com a adoção, pelas grandes corporações, de crescente fragmentação de partes da cadeia de valor adicionado (DUPAS, 2001).

Historicamente, as ETNs tenderam a concentrar suas funções mais elevadas de tomada de decisões e as atividades de 
GALVÃO, C.A. \& PEREIRA, V.F. Empresas transnacionais (ETNs) e os ... design e desenvolvimento tecnológico nas economias desenvolvidas gerando uma tendência geográfica importante no padrão de tipos de emprego em escala global.

Como mostra a United Nations Conference on Trade and Development (UNCTAD) (1994, apud DUPAS, 2001), em geral a qualidade do trabalho nas empresas transnacionais - salários, condições de trabalho ou benefícios- é melhor do que aquela que prevalece nos mercados locais. As corporações se concentram nas indústrias que são mais high skills e marketing intensive, tendendo a utilizar tecnologias mais capital-intensivas e técnicas organizacionais superiores à das empresas domésticas. No entanto, afirma Dupas (2001, p. 56) "existe um claro hiato entre os salários pagos pelas corporações nos países desenvolvidos e nos países em desenvolvimento".

Segundo Dicken (2010) as empresas transnacionais pagam muito mais aos trabalhadores nos países de alta renda do que àqueles nos países de baixa e média renda. Essas empresas pagam salários mais altos em geral do que as empresas domésticas na proporção de 1,4 nos países de alta renda, 1,8 nos países de média renda, e 2,0 nos de baixa renda de acordo com Dicken (2010, p. 501). Os estudos revisados por Fernández (2012) enfatizam que o salário pago por empresas transnacionais nos países em desenvolvimento é maior do que o salário médio nacional.

Fernández (2012) se baseou na análise de uma gama substancial de autores para afirmar que os investimentos das empresas transnacionais podem estimular o desenvolvimento local através do aumento e melhoria dos recursos e capacidades, o aumento da concorrência, uma melhor alocação de recursos, o desenvolvimento de recursos humanos. Ele também salienta que a transferência de métodos de trabalho inovadores aumenta a produtividade, que por sua vez aumenta o tempo disponível para outras atividades. Ademais, esse autor, mostra que a concorrência adicional pode incentivar as empresas existentes a melhorar a sua eficiência. No entanto, nem tudo é positivo nessas empresas, frequentemente causam danos ao meio ambiente, podem vender produtos nocivos, suas ações podem estar ligadas ao suborno e à corrupção. 
GALVÃO, C.A. \& PEREIRA, V.F. Empresas transnacionais (ETNs) e os ...

Dicken (2010) ressalta que os países mais pobres do mundo, quando atraem investimentos, atraem baixos níveis de investimentos direto estrangeiro. Um vasto volume de IDE mundial é direcionado para as economias desenvolvidas, enquanto a parte destinada aos países em desenvolvimento está concentrada em um pequeno número de países recém-industrializados.

De acordo com Baafi (2009) os países em desenvolvimento que receberam a maior parte do investimento das transnacionais são aqueles percebidos como tendo o maior potencial de crescimento. Eles são geralmente conhecidos como os novos países industrializados e incluem países asiáticos, como China, Singapura, Malásia, Tailândia e países latino-americanos, como México, Brasil e Argentina. Segundo Baafi (2009) os dez maiores receptores de investimento estrangeiros diretos recebem quase 95\% do total, enquanto todos os países africanos juntos recebem menos de $4 \%$, sendo que os 50 países mais pobres do mundo recebem menos de $2 \%$ do investimento das transnacionais.

Baafi (2009) enfatiza igualmente, que existem muitas incertezas associadas com as operações das ETNs. Como elas são altamente dinâmicas podem simplesmente fechar seus negócios em determinado país e se instalarem em outro. Isto acontece mais nas plantas mais antigas que necessitariam de upgrading para poderem permanecer ou nas plantas que podem ser facilmente vendidas sem muita perda. Se um país tem muitas empresas transnacionais na sua economia, torna-se muito vulnerável e enfrenta uma grande incerteza a longo prazo. Dessa forma, o país se vê forçado a oferecer vantagens às transnacionais sob a forma de subsídios, benefícios fiscais especiais e outras concessões, a fim de persuadilos a permanecer, sendo que essas vantagens ficam caras para os contribuintes dos países em desenvolvimento.

O custo de saída para o fechamento de uma unidade produtiva funciona como um freio à saída das transnacionais instaladas nos países mais pobres. E esse custo envolve, muitas vezes, considerável perda de capital (DUPAS, 2001), esse custo de saída pode ser visto como um aliado dos países periféricos, no 
GALVÃO, C.A. \& PEREIRA, V.F. Empresas transnacionais (ETNs) e os ...

sentido de reduzir a fuga das transnacionais para outros países com maior potencial de exploração.

Gomes (2003) salienta que por um longo tempo grande parte da literatura entendeu que as funções relevantes de criação e desenvolvimento das ETNs eram desenvolvidas unicamente dentro da matriz corporativa. No entanto, mais recentemente, alguns pesquisadores perceberam que as subsidiárias auxiliam a transnacional na criação de novos ativos que podem ser explorados por todas as unidades da corporação dispersas internacionalmente.

Gomes (2003) segue afirmando que as firmas líderes procuram se apropriar do conhecimento no estrangeiro através da dispersão das atividades tecnológicas, sendo este conhecimento uma fértil fonte de inovações que podem ser exploradas internacionalmente, inclusive por outras unidades da corporação. $\mathrm{O}$ autor segue afirmando que estas empresas têm alterado a natureza da criação tecnológica internacional através de uma pioneira integração das unidades das ETNs em redes regionais e globais, originando novas estruturas para a produção da tecnologia.

Gomes (2003) salienta que as subsidiárias das empresas transnacionais via, seus laboratórios, promovem a diferenciação internacional tanto de gostos dos consumidores e das fontes de conhecimentos, quanto das competências em pesquisas especializadas. Nas palavras de Gomes (2003, p. 125) "como a filial pode utilizar os seus saberes e as suas capacidades para desenvolver produtos que respondem às necessidades geograficamente diferenciadas de cada segmento de mercado, então está implícita alguma autonomia para a unidade local".

O núcleo central de pesquisa e desenvolvimento ainda assegura o equilíbrio e a coerência das operações globais, a evolução dos produtos ou das tecnologias, os elos de interdependência e as dimensões das tomadas de decisões, que se tornaram multifacetadas.

As ETNs são grandes geradoras de mudanças tecnológicas e quando alocam algumas de suas operações fora do seu país de origem, passam a fazer a transferência geográfica de tecnologias, 
GALVÃO, C.A. \& PEREIRA, V.F. Empresas transnacionais (ETNs) e os ...

disseminando essas tecnologias nos países hospedeiros. Assim, a população local se beneficia dessa transferência tecnológica através do treinamento em habilidades e técnicas específicas (DICKEN, 2010).

Peter Dicken (apud DUPAS, 2001) ao definir as características predominantes das corporações globais a partir de seu comportamento nos anos 80, destacava três: a competência em controlar sua atividade simultaneamente em vários locais do planeta; a capacidade de tirar vantagens dos diferentes fatores de produção entre países (neles incluídas as políticas governamentais); e a flexibilidade geográfica dada pelo deslocamento de seus recursos e operações em escala global.

Dupas cita Leonidas (1971, apud DUPAS, 2001) que enfatiza que os fatores com maior mobilidade, como tecnologia, gerenciamento e equipamento, são deslocados para o local daqueles menos móveis, permitindo que as corporações transnacionais possam utilizar o trabalho de países menos desenvolvidos em processos produtivos anteriormente associados apenas aos países mais industrializados, ou seja, baixos custos e técnicas avançadas.

Tendo analisado algumas das características da reconfiguração do capitalismo passaremos a analisar algumas das práticas espaciais das corporações transnacionais.

\section{Práticas espaciais das corporações transnacionais}

Mollo (2013) quando caracteriza a globalização destaca a importância do deslocamento espacial das diferentes etapas do processo de produção de forma a integrar vantagens nacionais diferentes. Kobrin (2008), por sua vez, ressalta que estamos no meio de uma mudança profunda na organização da política e da economia do mundo, uma transição para uma ordem transnacional ou pós-westfaliana que enfatiza as mudanças na natureza e significado do espaço geográfico.

Haesbaert (1994) argumenta que o território tem a ver com poder no sentido mais concreto, de dominação, bem como com o 
GALVÃO, C.A. \& PEREIRA, V.F. Empresas transnacionais (ETNs) e os ...

poder no sentido mais simbólico, de apropriação. Lefebvre, (apud HAESBAERT, 1994), distingue apropriação de dominação, a primeira sendo um processo muito mais simbólico, carregado das marcas do vivido, do valor de uso, o segundo mais concreto, funcional e vinculado ao valor de troca. Haesbaert (1994) afirma que o território imerso em relações de dominação e/ou de apropriação sociedadeespaço, desenrola-se ao longo de um continuum que varia desde a dominação político-econômica mais concreta e funcional até a apropriação mais subjetiva e/ou cultural-simbólica.

Lipietz (1994) refere-se ao movimento de desestruturaçãoreestruturação que se dá com a emergência de novos usos que se faz do território. De acordo com Santos (2006) é o uso do território e não o território em si mesmo, que faz dele objeto de análise. Sob a globalização, a interdependência universal dos lugares confere novos sentidos para o território, que provêm de sua reconceitualização como um dado básico do lugar, da região e das nações no contexto da competitividade, resguardadas as especificidades dos territórios dependentes das economias centrais.

Não devemos esquecer o que Harvey fala sobre a propensão para a dominação do espaço "que é muito mais profunda do que a mera racionalidade econômica" (2011, p. 129). Ele também alerta que o capitalismo "floresce melhor em um mundo geográfico de imensa diversidade de atributos físicos e condições sociais e culturais" (2011, p. 133). Para esse autor "a diversidade geográfica é uma condição necessária, e não uma barreira, para a reprodução do capital. Se a diversidade geográfica não existe ela deve ser criada" (2011, p. 133).

Segundo Corrêa (1992), no processo de organização do espaço a sociedade estabelece um conjunto de práticas por meio das quais são geradas, mantidas, desfeitas e refeitas a modelagem e as interações espaciais. Esse processo é denominado práticas espaciais, as quais impactam sobre o espaço, provocam alterações, sendo resultantes dos diversos projetos que são concebidos para viabilizar a existência de uma atividade de uma empresa, ou mesmo da própria sociedade. $\mathrm{O}$ autor segue argumentando que as práticas espaciais são recursos 
GALVÃO, C.A. \& PEREIRA, V.F. Empresas transnacionais (ETNs) e os ...

efetivos, por meio dos quais objetiva-se a gestão do território. Na fase atual do capitalismo as corporações transnacionais desempenham papel central na organização espacial, controlando porções do território de forma ampla e diferenciada.

Corrêa (1992) com base em suas reflexões sobre as práticas espaciais empresariais apresenta uma classificação em que distingue cinco modalidades de práticas espaciais: seletividade espacial, fragmentação-remembramento espacial, antecipação espacial, marginalização espacial e reprodução da região produtora. $\mathrm{O}$ autor lembra que essas práticas espaciais não são mutuamente excludentes, podem acontecer combinadamente ou apresentarem um caráter complementar espacial.

Para Corrêa (1992) a seletividade espacial diz respeito à seleção de localizações efetuada pelas corporações no seu processo de atuação. A decisão sobre a localização depende dos atributos presentes em um determinado lugar, julgados de utilidade para a corporação. Atributos clássicos como a proximidade de matéria prima e fontes de energia, ou o acesso ao mercado consumidor são características valorizadas pelas grandes corporações. A seleção de localizações é influenciada igualmente pela presença de um porto, de mão de obra não qualificada e pouco sindicalizada, ou especializada. As corporações industriais com produtos situados à montante ou à jusante de sua produção, centros de pesquisa, incentivos fiscais e infraestrutura adequada, compõem também o leque de características que podem influenciar a decisão de localização de uma unidade vinculada a uma corporação. Essas características, ressalta o autor, podem se apresentar isoladas ou combinadas, podem variar de um lugar para outro, além de serem avaliadas constantemente. $\mathrm{Na}$ reavaliação importa a natureza especifica de cada empresa a ser implantada. Se se trata de uma unidade de beneficiamento, escritório regional de vendas, centros de pesquisa ou depósitos atacadistas. A consequência desse processo é uma organização territorial complexa, tributária de um diversificado processo seletivo de lugares. Considerando que a corporação detém economias de escala ela pode criar algumas das características anteriormente mencionadas. Nesse 
GALVÃO, C.A. \& PEREIRA, V.F. Empresas transnacionais (ETNs) e os ...

caso, a seleção de uma localização depende da capacidade da corporação de dotar os lugares dos atributos necessários. Cabe mencionar que se a corporação detém controle sobre portos e usinas hidro elétrica exclusivos, seu controle sobre a gestão do território se torna mais efetivo.

Ainda conforme o mesmo autor, Fragmentaçãoremembramento também se constitui em uma prática espacial de uma corporação. Ela diz respeito a um processo que ora conduz à subdivisão de unidades espaciais em unidades menores, ora orienta-se para seu reagrupamento. $\mathrm{Na}$ remodelagem do seu território a corporação interfere na organização espacial de ampla porção de um pais ou região. A fragmentação é decorrente do processo de intensificação das atividades da empresa, em função da implantação de unidades novas, às quais se atribui um dado território. $\mathrm{Na}$ fragmentação há priorização para ocupação dos espaços com potencialidade maior em função do tipo das unidades que serão implantadas. Cabe salientar a existência de um aspecto temporal nesta prática espacial. Já o remembramento espacial constitui-se na face oposta à fragmentação. Ela diz respeito à aglutinação de unidades territoriais constituídas por um agregado de unidades menores, resultando em unidades territoriais mais amplas. O remembramento espacial pode estar relacionado à diminuição da oferta de produção no contexto de uma corporação. Por outro lado, é possível que as unidades menos adequadas, em termos de localização, sejam eliminadas em primeiro lugar. É importante lembrar que há uma seletividade espacial negativa, ou seja, a melhoria da acessibilidade pode também suprimir localizações que se viabilizavam apenas no contexto de circulação deficiente. Assim, fragmentação e remembramento constituem-se em práticas espaciais diferenciadas que podem ser usadas por uma referida corporação concomitantemente, mas em áreas diferentes.

A antecipação espacial ocorre quando uma unidade funcional da corporação é localizada em um dado lugar antes que os requisitos de localização tenham sido atendidos. A criação de um mercado consumidor e a oferta de matéria prima em limites 
GALVÃO, C.A. \& PEREIRA, V.F. Empresas transnacionais (ETNs) e os ...

satisfatórios serão posteriores à instalação da unidade produtora, evidenciando que a capacidade de previsão derivada do pioneirismo pode gerar lucros devidos à antecipação espacial. $\mathrm{O}$ autor lembra que esse procedimento apenas é possível para uma corporação multifuncional e multilocalizada com capacidade para assumir patamares diferenciados de remuneração, até mesmo níveis negativos entre suas diferentes unidades. A antecipação espacial quer dizer reserva de território, ou seja, a prerrogativa de que futuramente a corporação controlará uma determinada organização espacial, ampliando o seu espaço de atuação.

Já a marginalização espacial, por sua vez, vincula-se à perda de importância de um espaço ou localização, causada por transformações econômicas, tecnológicas ou políticas. Alterações locacionais frequentes na dinâmica produtiva de uma corporação envolvem frequentemente, um processo de abertura de novas unidades e a eliminação de outras. Essa dinâmica, por sua vez, conduz a uma seleção de lugares que outrora foram considerados pouco atrativos para implantação de novas unidades produtivas. Leva, por outro lado, à rejeição de lugares que foram anteriormente tidos como atrativos e que compunham de forma efetiva a rede de lugares da corporação. A marginalização espacial tem impactos variados, como, por exemplo, o nível de empregos e de arrecadação de impostos, por causa do fechamento de unidades da corporação, além daquelas indiretamente vinculadas a ela. A eliminação de unidades pode, porém, ser associada a uma reconversão funcional no âmbito da própria corporação. Neste caso trata-se de reconversão parcial, já que outra atividade substitui aquela que foi eliminada do lugar ou aí fica uma parcela de suas antigas funções. Cabe salientar que a marginalização espacial afeta também as interações espaciais dos lugares marginalizados situados fora da rede de ligação internas à corporação.

No que se refere à Reprodução da região produtora, Corrêa (1992) chama atenção para o controle do território, o qual se constitui em uma questão central, principalmente quando se trata de um território complexo, onde se localizam atividades múltiplas que 
GALVÃO, C.A. \& PEREIRA, V.F. Empresas transnacionais (ETNs) e os ... implica um conjunto muito variado de agentes que direta ou indiretamente participam de uma ou variadas etapas de seu complexo processo produtivo. $\mathrm{O}$ autor continua sua argumentação ressaltando que quando os interesses da corporação relacionam-se à atividade rural o controle territorial pode incluir uma gama de práticas que não se realizam pontualmente, como pode ocorrer em usinas de beneficiamento, fábricas, filiais de venda ou depósitos atacadistas. Assim o controle do território concretiza-se em áreas abarcando vários estabelecimentos com grande grau de contiguidade. Cada um desses estabelecimentos materializa-se em uma unidade jurídica, social e técnica, em relação a qual a corporação deve atuar. Cabe lembrar também que regiões pequenas ou grandes com tendência à especialização produtiva são criadas por meio da atuação da corporação, e assim submetidas ao seu controle.

Por fim, o referido autor salienta que essas são apenas algumas das práticas espaciais desenvolvidas pelas corporações no processo de gestão de suas atividades, as quais não esgotam o repertório. Outras práticas espaciais podem ser empreendidas pelas grandes corporações no seu processo de gestão do território, dependendo da sua área de atuação.

Tendo elaborado essa abordagem das práticas espaciais das corporações, que clarificam o movimento da globalização dos processos produtivos das transnacionais, passaremos a analisar as consequências da reconfiguração do capitalismo para os países periféricos.

\section{Consequências da reconfiguração do capitalismo para os países periféricos}

A fragmentação da produção permite a maximização na utilização dos recursos mundiais pelas transnacionais e coloca os países pobres como provedores de mão de obra barata. Esse processo vem contribuindo para uma flexibilização da mão de obra, porque, agora, os locais que não possuem vantagens comparativas na força de trabalho são facilmente substituídos por 
GALVÃO, C.A. \& PEREIRA, V.F. Empresas transnacionais (ETNs) e os ...

outros locais. Isso gera disparidades relevantes na criação de empregos entre países e regiões de países.

A mão de obra semiqualificada ou não qualificada podem ser usadas intensivamente nos países periféricos por causa da padronização com rotinização das tarefas. Sendo que no setor de microeletrônica são transferidas várias parcelas de trabalhointensivas do processo de produção, embora seja um produto novo e predominantemente capital-intensivo em suas demais etapas.

Stiglitz (2006) apresenta os benefícios das ETNs para os países em desenvolvimento: 1) aumentaram o padrão de vida por todo o mundo; 2) permitiram que bens produzidos em países em desenvolvimento alcançassem o mercado de países industrializados; 3) informam os produtores sobre as demandas do mercado internacional; 4) transferem tecnologia de países desenvolvidos para países em desenvolvimento; 5) transferem grandes volumes de recursos em forma de investimento direto estrangeiro; 6) criam emprego e geram crescimento econômico em países em desenvolvimento; 7) reduzem os custos dos produtos, entre outros.

Férnandez (2012) ressalta que os países menos desenvolvidos que estão fora das redes globais de empresas transnacionais estão em desvantagem considerável, principalmente por causa do comércio internacional que consiste em transferências intrafirma entre a sede, a sede e suas filiais e entre as filiais.

Fernández (2012) também ressalta que dentre as dificuldades internas de limitação do poder de barganha dos países menos desenvolvidos estão, em primeira instância, as suas instituições e leis deficientes, que não permitem o gerenciamento e controle das ações das empresas transnacionais e a falta de pesquisa e desenvolvimento (P\&D) que enfraquece ainda mais o seu poder de barganha. Outro agravante segundo Férnandez (2012) são as ações dos sindicatos e organizações sociais que fazem lobby junto aos governos que acabam sendo forçados a tomar decisões sobre o investimento direto estrangeiro. 
GALVÃO, C.A. \& PEREIRA, V.F. Empresas transnacionais (ETNs) e os ...

Stiglitz (2006) alerta para uma questão que não é normalmente considerada entre as consequências negativas da ação da ETNs, que é o fato de que as ETNs podem enfraquecer comunidades locais, uma vez que podem oferecer preços com os quais os negócios locais não podem competir - as consequências são o esvaziamento dessas comunidades e prejuízos ao seu desenvolvimento.

Para Fernández (2012) como os países menos desenvolvidos competem para atrair IDE, mas a maioria não têm a infraestrutura necessária, poucos acabam por atrair o IDE, assim ocorre a redução do potencial de convergência com os países desenvolvidos, criando um ciclo vicioso de pobreza.

Férnandez (2012) conclui que o cenário para os países menos desenvolvidos não é totalmente claro, uma vez que está cada vez mais difícil atrair IDE para os seus mercados, porque as empresas tendem a se estabelecer principalmente nos países desenvolvidos e naqueles classificados como emergentes, países esses que podem oferecer melhores vantagens locacionais que os países mais pobres.

As conclusões de dois países caribenhos (Trinidad e Tobago e Costa Rica) analisados por Dicken (2010) foram pessimistas mostrando que o investimento estrangeiro propiciou uma contribuição mínima para fortalecer os sistemas de inovações locais nesses países.

Dicken (2010) ressalta que as ETNs são frequentemente acusadas de exportar para os países em desenvolvimento tecnologias que são questionáveis em termos ambientais ou que são menos seguras do que parecem ser. No entanto, continua o autor, embora isso realmente possa ocorrer em casos específicos, nada comprova que se trata de uma prática consagrada. Ele cita o caso da hoje extinta empresa americana Enron que atropelou claramente as regulamentações ambientais em muitos lugares do mundo, provocando efeitos devastadores. Embora esse tenha sido um caso extremamente grave, segundo o autor, não se deve 
GALVÃO, C.A. \& PEREIRA, V.F. Empresas transnacionais (ETNs) e os ...

generalizar por conta deles, fazendo afirmações universais sobre o comportamento de todas ETNs em relação ao meio ambiente.

As ETNs tendem a transferir os resultados da inovação, mas não as capacidades inovadoras. Transferem o know-how (o conhecimento prático) no lugar do know-why (o conhecimento científico). Para Dicken (2010) as ETNs tendem a alocar a maior parte de suas atividades de criação de tecnologias nos seus países de origem ou nos países industrializados mais avançados, e em alguns dos países recém-industrializados mais avançados.

Os efeitos da transferência de tecnologia dos países desenvolvidos para os países em desenvolvimento podem ser positivos ou não. Dicken (2010) faz referência a um estudo do setor de componentes eletrônicos na Malásia, nas Filipinas e na Tailândia que foi bastante positivo tendo possibilitado a absorção de tecnologias latentes por parte das empresas locais.

Dicken (2010), além disso, mostra que enquanto as afiliadas estrangeiras das ETNs não se articularem junto às empresas locais, permanecerão como enclaves estrangeiros dentro de uma economia hospedeira. Para que isso não ocorra as ETNs têm que utilizar os vínculos interempresariais para a transmissão de tecnologia, fazendo pedidos junto a fornecedores domésticos de materiais ou componentes segundo as especificações rigorosas das ETNs, o que exige conhecimento técnico. Desta maneira, as empresas locais obtêm eficiência em mercados mais abrangentes. Por outro lado, o fornecimento de materiais localmente pode levar ao surgimento de novas empresas domésticas para atender à demanda gerada. Empregos adicionais são criados pelas atividades expandidas das empresas de abastecimento e das empresas de transporte e distribuição (DICKEN, 2010).

Segundo Dicken (2010) as ETNs levam algum tempo para estabelecer vínculos com os fornecedores locais. Por outro lado, as empresas fornecedoras no local precisarão algum tempo para adaptarem sua produção às necessidades das ETNs. Em muitos países em desenvolvimento, a base de fornecedores existentes não é suficientemente desenvolvida para atender aos critérios da ETN por isso 
GALVÃO, C.A. \& PEREIRA, V.F. Empresas transnacionais (ETNs) e os ...

a capacidade de absorção é muito baixa. Esse autor ilustra o argumento com o caso das fábricas maquiadoras mexicanas onde menos de $5 \%$ dos insumos utilizados são abastecidos dentro do México.

Dicken (2010) ressalta que sem o capital, a tecnologia e o acesso aos mercados que podem ser propiciados com o engajamento em redes de produção transnacionais, muitos locais seriam muito mais pobres porque não estariam vinculados a essas estruturas maiores.

O IDE é um influxo de capital para as economias hospedeiras, no entanto, em algum momento, ocorrerá uma inversão do fluxo, à medida que a empresa estrangeira transfira os ganhos e lucros de volta para a matriz. Com o tempo, esse fluxo de saída pode exceder o fluxo de entrada (DICKEN, 2010).

A entrada das empresas transnacionais em uma economia hospedeira pode induzir à redução no número de empresas e pode, igualmente, aumentar a concentração em empresas de grande porte. Tem sido normalmente aceito na literatura que o envolvimento das ETNs em determinada economia hospedeira poderá destruir o empreendimento doméstico, no entanto também podem ocorrer efeitos positivos como incentivos para o aumento dos negócios locais, bem como a possibilidade de criação de novas empresas em resposta ao estímulo da demanda por materiais e componentes.

Dicken (2010) lembra que embora a equipe de trabalho da ETN nos países em desenvolvimento continue concentrada em ocupações de produção e montagem de pouca qualificação, a proporção de trabalhadores mais qualificados empregados pelas ETNs nos países em desenvolvimento tende a aumentar com o passar do tempo, assim como a proporção de profissionais locais e equipe administrativa.

Como as ETNs são muito rigorosas e exigentes na contratação de empregados, irão fatalmente competir com as empresas locais já existentes, não buscarão preencher seus quadros dentre os desempregados, assim, cria-se competição pela mão de obra mais qualificada entre as ETNs e as empresas locais. 
GALVÃO, C.A. \& PEREIRA, V.F. Empresas transnacionais (ETNs) e os ...

Dicken (2010) salienta que um alto nível de dependência em relação a empresas estrangeiras reduz a possibilidade das empresas subsidiárias tomarem suas próprias decisões e implementá-las, reduzindo assim, a soberania e autonomia do país hospedeiro, com isso, quando boa parte da atividade econômica do país hospedeiro for efetivamente controlada por empresas estrangeiras, as metas não nacionais poderão se tornar dominantes. No entanto, outros autores a exemplo de Gomes (2003) mostram uma visão mais otimista. Esse autor ressalta que como o processo evolutivo da filial é apenas monitorado ou imprecisamente controlado, as subsidiárias acabam tendo certa autonomia que lhes permite iniciativas visando obter mandatos de produtos mundiais.

Gomes (2003) salienta que a dispersão da tecnologia é limitada pela crescente complexidade requerida pelos mecanismos de controle e de coordenação. Assim, a descentralização tecnológica tem se apresentado como geograficamente direcionada e limitada às nações industrializadas e ainda fortemente concentrada nos países de origem das ETNs.

Para Gomes (2003), no entanto, esta descentralização se mantém relativamente concentrada em termos geográficos. Sendo que o impacto espacial da globalização reforça a especialização através da maior sintonia entre cada unidade da rede de produção global e as instituições locais. A globalização envolve dispersão e integração que juntas moldam a localização espacial da atividade econômica, sendo que a dispersão estabelece a extensão das transações econômicas através das fronteiras nacionais, elevando a mobilidade internacional das finanças, da tecnologia, das habilidades empresariais e organizacionais. Neste processo de integração prevalecem a desigualdade e a diversidade, onde a dispersão concentrada, enfatiza esse autor, caminha lado a lado com formas de integração crescentemente complexas e sistêmicas.

Como as corporações transnacionais não possam enfrentar sozinhas a concorrência, em todos os mercados de atuação, elas externalizam muitas atividades produtivas e tecnológicas, criando, assim, via essa transferência, as condições para a prospecção de 
GALVÃO, C.A. \& PEREIRA, V.F. Empresas transnacionais (ETNs) e os ...

ativos tecnológicos que podem ser apropriados internamente pelas empresas terceirizadas nos países hospedeiros, tornando-as capazes de se diferenciar de seus competidores.

Gomes (2003) se refere à Cantwell e Janne (1999, apud GOMES, 2003) que concluíram que as grandes empresas líderes em tecnologia estão se movendo em direção a uma estratégia internacional de desenvolvimento tecnológico que cria os elos de uma cadeia de inovações geograficamente dispersos, mas complementares através da rede internacional de pesquisa.

Gomes (2003) também salienta que por um longo tempo as empresas transnacionais centralizaram suas atividades mais importantes, como a administração superior, o planejamento estratégico e a maioria dos laboratórios de $\mathrm{P} \& \mathrm{D}$, enquanto as subsidiárias assumem as funções diretamente ligadas à produção propriamente dita permitida pela rotinização de tarefas, utilizando processos altamente intensivos em mão de obra. Esse autor lembra que a literatura simbolicamente associou esta estrutura com a figura de um polvoa cabeça (sede da empresa) situada no país de origem e os tentáculos (subsidiárias) estendidos em regiões do estrangeiro. Entretanto, a globalização introduziu importantes mudanças na organização internacional da produção que está transferindo funções corporativas que comumente eram privilégio de um (ou poucos) sítio(s) no país de origem. Então, como bem diz esse autor, importantes funções do cérebro do polvo estão fluindo em direção aos tentáculos. Parece que a dinâmica capitalista está impondo profundas mudanças nas antigas estruturas corporativas. Gomes lembra o que muito corretamente observou J. Schumpeter, que o sistema capitalista necessita destruir as suas próprias estruturas para se reconstruir.

As ETNs podem tanto adquirir e transferir inovação através da rede geograficamente dispersa, quanto se apropriar dos efeitos benéficos da combinação e recombinação de tecnologias dos diferentes locais. Com o aumento da dispersão geográfica e a duplicação de capacidades tecnológicas a empresa transnacional conquista grande liberdade para deslocar as suas atividades e os seus projetos para as localidades mais propícias à pesquisa e 
GALVÃO, C.A. \& PEREIRA, V.F. Empresas transnacionais (ETNs) e os ...

desenvolvimento. Com a absorção de conhecimento de outras regiões a ETN pode criar condições para sustentar e estimular o esforço tecnológico nos países centrais.

Desta forma, salienta Gomes (2003), incentivando a troca de conhecimento e a (re)combinação de tecnologias internacionalmente, as atividades realizadas pelas subsidiárias no estrangeiro podem originar em fertilização cruzada entre as unidades dispersas geograficamente, engajadas em tipos similares de atividades de inovação.

Resumindo as observações de Gomes (2003) podemos dizer que as subsidiárias das empresas transnacionais nos países emergentes passaram a ter um papel mais ativo no processo criativo e deixam de ser simples escoadouro da efetiva aplicação de tecnologia de produtos centralmente desenvolvidos. Assim elas deixam de ser meras seguidoras e aplicadoras da tecnologia produzida nos países centrais para passarem a ter um papel importante na geração de novas tecnologias e novos produtos que passam a ser incorporados na rede de produção global.

Tendo analisado algumas das principais nuances das novas espacializações da produção das empresas transnacionais e suas consequências nos países centrais e periféricos, faz-se necessário analisar as possibilidades de ação para conter as consequências negativas que as transnacionais causam, em especial nos países periféricos, ainda que tenham sido constatadas consequências positivas, o que será feito no item que se segue.

\section{Governança global e o papel do estado}

A economia mundial se transformou em uma economia de mercado capitalista global. Com o colapso dos sistemas socialistas estatais, no final da década de 1980, que passam cada vez mais a se integrarem às economias de mercado e com a abertura parcial da economia chinesa a partir de 1979, foi criado um sistema global muito diferente daquele surgido depois da Segunda Guerra Mundial. Novos e crescentes fluxos de produtos, serviços e finanças geraram um mundo cujas regras de controle não acompanharam as mudanças e 
GALVÃO, C.A. \& PEREIRA, V.F. Empresas transnacionais (ETNs) e os ...

transformaram as relações econômicas, geográficas e de poder. Dicken (2010) enfatiza a argumentação de Susan Strange que mostra que o poder se deslocou para cima, de Estados enfraquecidos para Estados mais fortalecidos, com alcance regional ou global além de suas fronteiras e que o poder se deslocou lateralmente, de Estados para mercados e, daí, para autoridades não estatais que derivam seu poder de suas fatias de mercado.

A globalização tem inúmeros aspectos positivos e ela é essencial para os países em desenvolvimento, mas medidas devem ser tomadas para minimizar seus danos e maximizar seus benefícios. Stiglitz se preocupa com a impunidade de ações nocivas e muitas vezes ilegais das ETNs porque, em suas palavras "é difícil imputar responsabilidade das decisões em um indivíduo uma vez que ele se esconde na máquina empresarial e muitas vezes é protegido pelo governo de seu país de origem - seus investidores estão protegidos por sua responsabilidade limitada, cujo único risco seria perder seu investimento" (STIGLITZ, 2006, p. 192).

Stiglitz (2006) mostra que a competição entre países em desenvolvimento pela atração de investimentos pode se tornar uma competição de fragilidades onde o país que tiver menos leis trabalhistas e ambientais ganha.

Fica evidente que em função da marcha das transnacionais sobre as economias periféricas com o objetivo de reduzir custos, consequências nefastas ocorrem, conforme anteriormente discutido, o que mostra a ausência ou fraqueza de instâncias globais reguladoras que, quando muito, atendem aos interesses do capital financeiro globalizado, das transnacionais e dos países desenvolvidos. Nesse sentido, como salienta Pochmann (2004) existe desigualdade de recursos políticos, que opõe os agentes globalizadores a entidades com reduzidos recursos políticos: os governos de boa parte dos países em desenvolvimento e a sociedade civil.

Como as forças de desintegração superam as forças de integração no novo cenário econômico mundial, e como a economia global é assimétrica, sobrepondo-se às dinâmicas econômicas e sociais nacionais, novos parâmetros de cooperação 
GALVÃO, C.A. \& PEREIRA, V.F. Empresas transnacionais (ETNs) e os ...

internacional atenuam ou revertem as consequências negativas da expansão do capitalismo global.

Pochmann (2004, p. 34) afirma que "A nova onda de globalização avança de forma fragmentária, puxada pelos grupos econômicos poderosos, mas sem um projeto político explícito que estabeleça compromissos e contrapesos, abrindo mão de um processo formal de negociações, como no pós-Segunda Guerra Mundial”.

Entre as consequências deletérias do avanço das transnacionais dentro do processo de globalização durante os anos noventa, deve-se enfatizar a tendência de agravamento da polarização no seio dos até então chamados países em desenvolvimento, ampliando-se a diferença entre a semi-periferia e a periferia, sendo que esta engloba países que se mantiveram dependentes da produção e exportação de produtos primários e minerais e dos investimentos externos na indústria e na infraestrutura.

Ascani, Crescenzi e Immarino (2012) argumentam que anteriormente aos anos 1980 os Estados nacionais desempenhavam um importante papel na regulação, orientação e na restrição do volume do comércio internacional e na mobilidade de capitais entre os países, mas esse equilíbrio se desfaz após a década de 1980. A globalização tem gradualmente reduzido a importância das instituições econômicas em nível do Estado-nação, tais como eram conhecidas no período pós-Segunda Guerra Mundial.

Para Dupas (2001) o que existe é uma demanda urgente por um novo Estado, que seria algo entre o Estado mínimo e o Estado forte, ou seja, um Estado em que as forças de mercado e as do Estado coexistissem de forma harmônica e equilibrada. O papel deste novo Estado seria o de indutor-normativo-regulador. Para esse autor, o Estado-rede é um Estado cuja principal característica é a capacidade de impor uma decisão ao longo de uma rede de instituições, atuando nos níveis global e local. O desafio que esse Estado enfrenta é o de lidar com o poderio crescente das empresas transnacionais, além do desafio de garantir o crescimento econômico, o emprego, ou seja, o desenvolvimento. 
GALVÃO, C.A. \& PEREIRA, V.F. Empresas transnacionais (ETNs) e os ...

Dupas (2001) também enfatiza que os Estados não são agentes passivos, pois preservam a capacidade de induzir a formação das cadeias globais. Esse autor também ressalta que os Estados têm condições de impor uma série de limites para a atuação das ETNs, por exemplo, estabelecendo exigências quanto à participação nacional nos produtos. $\mathrm{O}$ desenvolvimento requer um Estado atuante e catalisador, facilitando, encorajando e regulando o setor privado, garantindo os direitos fundamentais, criando um aparato legal e institucional que limite o poder das ETNs.

Férnandez (2012) lista as possíveis ações de contenção dos comportamentos nocivos das ETNs:

1) Ações dos governos nacionais via leis e instituições que impeçam esse tipo de abuso;

2) Ações das agencias supranacionais, como a Organização Mundial de Comércio (OMC) ou outra organização internacional, responsáveis pela regulação dos investimentos diretos estrangeiros e das ETNs. A OMC deveria estabelecer regras internacionais claras e justas sobre as atividades das ETNs, ainda que algumas ações já tenham sido implementadas, como o Foreign Corrupt Practices Act Abroad, que é apoiado por um grande número de empresas norte-americanas;

3) Ações das organizações nacionais e internacionais da sociedade civil para regular os abusos de empresas multinacionais.

Stiglitz (2006), por seu turno, compõe uma agenda com cinco pontos para minimizar os abusos cometidos por ETNs:

1) Tornar mais abrangente a responsabilidade social corporativa - a responsabilidade das ETNs vai além de seus acionistas e as boas ações podem beneficiar os negócios, ao passo que ações abusivas podem gerar processos caros e prejudicar a imagem da empresa, mesmo que em países distantes. Por outro lado, a empresa pode atrair força de trabalho de maior qualidade e seus empregados ficarão mais satisfeitos em trabalhar em uma firma com responsabilidade social;

2) Limitar o poder das corporações - restringir a competição é outra maneira encontrada pelas ETNs para aumentar seus lucros 
GALVÃO, C.A. \& PEREIRA, V.F. Empresas transnacionais (ETNs) e os ...

por meio de comportamentos anti-competitivos com tendência para formação de cartéis. Ainda que as ETNs tenham recebido, em alguns casos, punições nos Estados Unidos da América e na União Européia, raramente são punidas nos países pequenos e pouco desenvolvidos. Para Stiglitz (2006) com a formação de monopólios dentro da globalização faz-se necessária uma regulação global com autoridade para aplicar punições civis e criminais quando o comportamento monopolista afetar mais de uma jurisdição;

3) Aperfeiçoar a governança corporativa - o foco dessa reforma seria nas leis que governam as próprias corporações de modo que elas atuem de maneiras mais consistentes com o interesse público, assim, se uma ETN está disposta a operar em certo país deve aderir ao sistema legal desse país;

4) Criar uma legislação global para uma economia global de forma a permitir processos de ação coletiva de grupos de indivíduos prejudicados pelas ETNs, pois em grupo eles tem maior chance de terem suas demandas atendidas mais rápido. $\mathrm{O}$ acesso à justiça deve ser globalizado garantindo assistência legal generalizada;

5) Reduzir o domínio da corrupção - criando leis contra a corrupção no exterior.

Stiglitz (2006) reconhece a dificuldade de implementar essas ideias, porém afirma que existem movimentos que em conjunto com a sociedade civil e com a utilização de tecnologia estão monitorando as atividades das ETNs e controlando seus abusos.

Com relação aos movimentos sociais antiglobalização devese citar um parágrafo apresentado por Dicken (2010) que resume suas principais nuances bem como sua diversidade. Eles abrangem grupos de pressão de antigas ONGs, como Oxfam, Greenpeace e Friends of the Earth; grupos mais recentes, como o Jubilee 2000; sindicatos de trabalhos organizados; organizações de apoio ao trabalho, como a Women Working Worldwide ou a Maquila Solidarity Network; organizações focadas basicamente em ETNs e grandes corporações (como Corporate Watch ou Global Exchange); outros grupos nacionalistas/populistas de direita (exemplificados por figuras como Pat Buchnan nos Estados 
GALVÃO, C.A. \& PEREIRA, V.F. Empresas transnacionais (ETNs) e os ...

Unidos, ou o partido de extrema direita de Jean-Marie Le Pen na França); grupos anticapitalistas (como o Socialist Workers Party); e vários grupos anarquistas. Dicken (2010), no entanto, mostra que os programas dessas instituições, muito frequentemente, são contraditórios. As próprias organizações globais da sociedade civil têm atraído muitas críticas com questionamentos sobre sua legitimidade e, em alguns casos, sobre sua capacidade de elaborar metas de desenvolvimento socioeconômico para os pobres.

Dicken (2010) segue argumentando que as organizações globais da sociedade civil, por serem as criadoras, defensoras e juízes dos valores e padrões globais, obrigam as pessoas, os políticos e os líderes empresariais a reconhecerem e a se envolverem com uma realidade inconveniente na qual os benefícios e os custos da globalização são distribuídos de modo muito desigual, e a reconhecerem, igualmente, que existem problemas graves e tensões que precisam de solução.

Um avanço potencialmente expressivo foi o surgimento no Brasil do Fórum Social Mundial em 2001, congregando diversas organizações não governamentais. Este fórum foi estabelecido em resposta à agenda econômica neoliberal do Fórum Econômico Mundial (DICKEN, 2010).

De acordo com Dicken (2010) a Organização Mundial do Comércio (OMC) continua sujeita a muitas críticas tanto nos países desenvolvidos como nos em desenvolvimento. Sendo este órgão considerado antidemocrático e que atua, principalmente, em prol dos interesses das corporações globais. Um problema apontado por Dicken (2010) diz respeito ao fato de que os pequenos países em desenvolvimento participam pouco no processo de negociação na $\mathrm{OMC}$, devido à carência de recursos.

Na realidade, segundo Dicken (2010) existe um histórico de tentativas de introduzir uma estrutura internacional relacionada a investimentos diretos estrangeiros e ETNs: orientações da Organização para Cooperação e Desenvolvimento Econômico (OCDE) para Empresas Multinacionais (introduzidas pela primeira vez em 1976); declaração Tripartite de Princípios da Organização Internacional do 
GALVÃO, C.A. \& PEREIRA, V.F. Empresas transnacionais (ETNs) e os ...

trabalho (OIT) para Empresas Multinacionais e Política Social (1977); código das Nações Unidas de Conduta para Empresas Multinacionais; e Organisation for Economic Co-operation and Development (OECD) Multilateral Agreement on Investment (MAI). A tentativa mais recente foi lançada em meados de da década de 1990.

Para Stiglitz (2006) as ETNs se tornaram o símbolo da globalização e, portanto, são identificadas por muitas pessoas como a principal causa dos problemas decorrentes - algumas ETNs tem mais poder econômico que muitos países e até mesmo que grupos de países. Fernández (2012) contesta esse argumento de Stiglitz e de outros autores que diz respeito ao fato de que as empresas transnacionais são mais poderosas do que os governos nacionais. Dizse que as maiores empresas transnacionais do mundo têm orçamentos maiores do que alguns países em desenvolvimento. No entanto, esta crítica não tem veracidade porque, em primeiro lugar, na arena política, essas empresas não podem ser comparadas com a capacidade de coerção que o governo tem sobre seus cidadãos. Neste sentido, os governos nacionais continuam a ter o papel central. Se as empresas transnacionais estão sob a jurisdição de uma determinada nação, terão que agir conforme as leis daquela nação. As críticas de que essas empresas são economicamente mais poderosas do que alguns países se baseia na comparação das vendas dessas empresas com o produto interno bruto destes países, que, no entanto, não são variáveis comparáveis, não medem a mesma coisa. Grauwe e Camerman (apud FERNÁNDEZ, 2012) realizaram um estudo comparando o valor agregado das empresas transnacionais e o resultado contradiz radicalmente essa crítica. Os autores concluem que "as empresas são surpreendentemente pequenas em comparação com outros Estadosnação" (apud Férnadez, 2012, p. 95). Assim, os Estados-nação permanecem sendo os atores mais importantes comparativamente às empresas transnacionais.

Férnandez (2012, p. 96) analisando os relatórios da UNCTAD de 2007 e 2011, observa que entre 1992 e 2010, mais de 2.800 mudanças regulatórias nas legislações nacionais de IDE foram feitas em todo o mundo, onde apenas $10 \%$ dessas mudanças 
GALVÃO, C.A. \& PEREIRA, V.F. Empresas transnacionais (ETNs) e os ...

foram menos favoráveis para o IDE, enquanto o resto foi uma maior liberalização.

Rodrik (2011) se propõe a discutir a governança global e a tentar elucidar se ela é viável ou mesmo desejável. Esse autor ressalta que vivemos em um mundo cuja governança foi radicalmente transformada pela globalização, mas que o cerne da questão ainda permanece com os formuladores de políticas domésticas. Para esse autor o propalado declínio do Estado-nação é apenas alarde. Isso porque embora a economia mundial seja preenchida por uma multiplicidade de agências internacionais a tomada de decisões democrática permanece firmemente inserida no escopo dos Estados-nação. E ele afirma que a governança global, ainda que tenha um grande apelo, ainda é um conceito em construção. Como o nosso mundo é complexo e diversificado, a existência de uma governança global ainda é um conceito muito incipiente.

No entanto, Rodrik (2011) acrescenta que muitos teóricos percebem evidências de que novos modelos de governança global estão emergindo, entre eles ele cita Anne-Marie Slaughter, que analisou as redes transnacionais que podem desempenhar funções de governança, onde técnicos de regulação, juízes e até mesmo legisladores têm um papel ativo. Rodrik apresenta a argumentação de Slaughter (2004, apud RODRIK 2011) sobre as redes transnacionais, onde ela afirma que essas redes estendem o alcance dos mecanismos formais de governança, permitindo que a persuasão e partilha de informações que atravessam as fronteiras nacionais, contribuam para a formação de normas globais, e possam gerar a capacidade de implementar normas e acordos internacionais em nações onde a capacidade nacional para fazê-lo é fraca.

Por outro lado Rodrik (2011) coloca a argumentação de John Ruggie (2004, apud RODRIK 2011), que afirma que essas redes podem ir além das áreas estritamente técnicas e abarcar fins sociais mais amplos. Ruggie advoga uma maior ênfase na responsabilidade social das empresas a nível global. Ruggie, autor do conceito "liberalismo enraizado", mostra que esse se deslocaria de um 
GALVÃO, C.A. \& PEREIRA, V.F. Empresas transnacionais (ETNs) e os ...

multilateralismo centrado no Estado para um multilateralismo que abraçasse ativamente a contribuição potencial da sociedade civil e atores corporativos para as organizações sociais globais. Esses atores poderiam aperfeiçoar as novas normas globais - sobre os direitos humanos, práticas trabalhistas, saúde, combate à corrupção e gestão ambiental - e então consagrá-las nas operações das grandes corporações internacionais e nas políticas dos governos nacionais.

Rodrik (2011) mostra que em um Estado-nação o processo eleitoral garante a legitimidade da representação, enquanto no caso da governança global a responsabilização das normas regulatórias não é clara. Outro aspecto abordado pelo autor é o fato de que a governança global requer indivíduos que venham a agir como cidadãos do mundo.

Rodrik (2011) discute o caso da União Europeia, mostrando que ela é a exceção que confirma a regra, pois é um exemplo do potencial para a governança global bem como das limitações dela. As nações europeias alcançaram uma extraordinária integração entre elas, com a criação de uma enorme quantidade de artifícios institucionais para remover custos transacionais e criar harmonização nas regulações que permitiram que a Europa se tornasse economicamente mais integrada do que qualquer outra região do mundo, mas com uma estrutura de governança em construção. A evolução institucional da União Europeia tem progredido de forma lenta e subsistem grandes diferenças entre os Estados membros. O aprofundamento da integração política da Europa se torna problemática à medida que o número de membros aumenta e a composição da União Europeia torna-se mais diversificada. O autor aponta que o dilema da Europa não é diferente do que o que é enfrentado pela economia mundial como um todo e que para profundar a integração econômica faz-se necessário erigir uma extensa estrutura de governança transnacional. O autor conclui que a União Europeia prova que a governança global é viável, mas sua experiência revela as rigorosas exigências de tal governança. 
GALVÃO, C.A. \& PEREIRA, V.F. Empresas transnacionais (ETNs) e os ...

Rodrik (2011) mostra que a governança global tem limitações, pois oferece pouca ajuda para resolver os desafios para solucionar problemas enraizados em profundas divisões entre as diferentes sociedades em termos de preferências, circunstâncias e capacidades. Nesse caso, segue o autor, as regulações técnicas não ajudam, tampouco ajudam as redes de reguladores, ou as soluções baseadas no mercado, ou a responsabilidade social corporativa, ou mesmo a deliberação transnacional, formas de governança essas que apenas conseguem lançar uma tênue luz na governança global nesse mundo extremamente diversificado que não pode ser reduzido a uma única comunidade política.

Rodrik (2011) ao discutir os conceitos de identidade e globalização, apresenta os achados do World Values Survey que efetua periodicamente pesquisas por meio de amostras aleatórias com pessoas em todo o mundo sobre suas atitudes e pertencimentos. A recente rodada de pesquisas inquiriu pessoas em cinquenta e cinco países sobre suas identidades locais, nacionais e globais. Os resultados foram semelhantes em todo o mundo e revelaram que a identificação com o Estado-nação supera todas as outras formas de identidade. As pessoas se veem em primeiro lugar como cidadãos de sua nação, em seguida como membros de sua comunidade local e somente em último lugar como cidadãos globais.

Rodrik (2011) apresentou informações baseadas nessas pesquisas que revelam uma cisão considerável entre as elites e o resto da sociedade. Um forte sentido de cidadania global tende a existir nas classes mais abastadas e naquelas com maiores níveis de instrução, enquanto a identificação com o Estado-nação é geralmente muito mais forte (e identidades globais correspondentemente mais fracas) entre os indivíduos de classes sociais mais baixas. E o autor atribui esses achados ao fato de que os profissionais qualificados e investidores poderem se beneficiar de oportunidades globais. O Estado-nação e o que ele faz importa sobremaneira para os trabalhadores menos móveis e outros com menos competências que têm de se contentar com o que está nas proximidades. Assim, para Rodrik (2011), a construção de comunidades políticas transnacionais é um projeto das elites 
GALVÃO, C.A. \& PEREIRA, V.F. Empresas transnacionais (ETNs) e os ... globalizadas interessadas nas oportunidades oferecidas pela globalização.

Para Rodrik (2011) as novas formas de governança global se deparam com alguns limites fundamentais: identidades políticas e pertencimentos ainda giram em torno de Estados-nação; a representação política da sociedade é organizada internamente e não globalmente; normas globais verdadeiras surgiram apenas em uma reduzida gama de questões; e continuam a existir diferenças substanciais em todo o mundo sobre acordos institucionais desejáveis. $\mathrm{O}$ que fica claro na exposição do autor é que esses mecanismos são insuficientes para sustentar uma globalização econômica mais ampla.

\section{Considerações finais}

As empresas transnacionais tornam-se maiores e mais poderosas, tão poderosas que vêm o mundo como um espaço único de aplicação de suas operações de investimento e produção. Em sua luta por melhores e mais lucrativas iniciativas de investimentos incorporam áreas de países pobres apenas enquanto não existirem oportunidades alternativas de exploração em outros países, assim esses investimentos se transferem de país a país, territorializando e desterritorializando. Nesse movimento as corporações se apropriam das vantagens oferecidas pelos governos de cada nação, os quais criam atrativos para que as empresas se instalem aumentando as oportunidades de emprego e crescimento econômico para os países hospedeiros, através da manipulação dos instrumentos de política econômica.

Até meados do século XX, as empresas transnacionais eram geralmente vistas como agentes internacionais de exploração. No entanto, com a intensificação do processo de globalização, a partir do final dos anos setenta e ainda hoje, os países menos desenvolvidos começaram a apreciar os benefícios das transnacionais.

Entre os efeitos positivos do processo de avanço das transnacionais nos países em desenvolvimento estão os empregos gerados pela implantação da filial e seus efeitos multiplicadores 
GALVÃO, C.A. \& PEREIRA, V.F. Empresas transnacionais (ETNs) e os ...

sobre outros setores. Para cada emprego criado pelas corporações é gerada uma quantidade muito maior de empregos, principalmente por meio de suas compras de matérias-primas, componentes, serviços de subcontratados e fornecedores externos, inclusive pelos elos existentes entre as empresas transnacionais e os distribuidores do produto final. Também não podemos deixar de mencionar que o salário pago por empresas transnacionais nos países em desenvolvimento é maior do que o salário médio nacional.

Além disso, os investimentos das empresas transnacionais podem estimular o desenvolvimento local através do aumento e melhoria dos recursos e capacidades, o aumento da concorrência, uma melhor alocação de recursos, o desenvolvimento de recursos humanos e pela transferência de métodos de trabalho inovadores que levam ao aumento da produtividade. Aumento esse que ocorre porque como as ETNs são grandes geradoras de mudanças tecnológicas, quando alocam algumas de suas operações fora do seu país de origem, passam a fazer a transferência geográfica de tecnologias, disseminando essas tecnologias nos países hospedeiros, e como consequência técnicas específicas são desenvolvidas.

Um outro aspecto positivo é que a mão de obra semiqualificada ou não qualificada podem ser usadas intensivamente nos países periféricos, por causa da padronização com rotinização das tarefas, utilizando, assim, mais intensivamente os recursos de mão de obra que têm maior disponibilidade nesses países.

Concordamos com Stiglitz (2006) que coloca o aumento do padrão de vida por todo o mundo entre os benefícios das ETNs para os países em desenvolvimento, permitindo que bens produzidos nesses países alcancem o mercado de países industrializados. Por outro lado, concordamos com Férnandez (2012) que ressalta que os países menos desenvolvidos que estão fora das redes globais de empresas transnacionais estão em desvantagem considerável, principalmente porque o comércio internacional consiste em transferências intrafirma entre uma filial e outra. No entanto, também podem ocorrer efeitos positivos como incentivos para o aumento dos negócios locais, bem como a 
GALVÃO, C.A. \& PEREIRA, V.F. Empresas transnacionais (ETNs) e os ...

possibilidade de criação de novas empresas em resposta ao estímulo da demanda por materiais e componentes.

O que ficou claro na análise desenvolvida nesse trabalho é que os países periféricos, embora se beneficiem por algum tempo do avanço das multinacionais em seus territórios através do processo de fragmentação da produção em nível global, na busca da redução dos custos totais, quer seja pelo impulso positivo em suas economias locais, quer seja pelos salários mais altos que os que em média são oferecidos pelas empresas nacionais, também sofrem consequências negativas do avanço desse processo.

Embora os efeitos positivos do avanço das ETNs sejam muitos e de grande impacto sobre o crescimento dos países em desenvolvimento, não se pode deixar de mencionar que existem substanciais efeitos negativos desse processo. Entre eles devemos enfatizar que no processo de incorporação de países periféricos nas redes globais, as transnacionais avançam de forma desigual, escolhendo os países da semiperiferia, países estes que se apresentam melhor equipados para o processo da produção transnacional, deixando ao abandono os países periféricos. Dessa forma ocorre o aprofundamento das diferenças entre os países menos desenvolvidos, ampliando ainda mais o fosso que separa os países desenvolvidos dos países mais pobres do mundo, os países periféricos. O resultado é a redução do potencial de convergência com os países desenvolvidos, e entre os países mais pobres, criando um ciclo vicioso de pobreza.

Os países mais pobres do mundo não atraem altos níveis de investimentos direto estrangeiro e em alguns casos, sequer o atraem. O investimento direto estrangeiro é preferencialmente direcionado para as economias desenvolvidas, enquanto a parte destinada aos países em desenvolvimento está concentrada em um pequeno número de países recém-industrializados.

Um outro efeito nefasto é a ampliação do emprego informal que cresce a passos maiores que o emprego formal. Mas embora a qualidade dos empregos gerados na periferia seja de qualidade inferior aos empregos gerados nos países sedes, não se pode deixar 
GALVÃO, C.A. \& PEREIRA, V.F. Empresas transnacionais (ETNs) e os ...

de destacar que são melhor remunerados que os empregos oferecidos nos países pobres, ainda que os salários pagos pelas corporações nos países desenvolvidos sejam muito mais elevados do que os que elas pagam nos países em desenvolvimento.

Como as ETNs são altamente dinâmicas podem simplesmente fechar seus negócios em determinado país e se instalarem em outro, dessa forma o país se vê forçado a oferecer vantagens às transnacionais sob a forma de subsídios, benefícios fiscais especiais e outras concessões.

Do ponto de vista da inovação também observamos efeitos negativos, porque as ETNs tendem a transferir os resultados da inovação, mas não as capacidades inovadoras, bem como, tendem a alocar a maior parte de suas atividades de criação de tecnologias nos seus países de origem ou nos países industrializados mais avançados, e em alguns dos países recém-industrializados mais avançados. No entanto, evidências do estudo seminal de Gomes (2003) aponta que como o processo evolutivo da filial é apenas monitorado ou imprecisamente controlado, as subsidiárias acabam tendo certa autonomia que lhes permite a busca de inovações tecnológicas que as tornam mais hábeis para competir.

As ETNs podem tanto adquirir e transferir inovação através da rede geograficamente dispersa, quanto se apropriar dos efeitos benéficos da combinação e recombinação de tecnologias dos diferentes locais. Com o aumento da dispersão geográfica e a duplicação de capacidades tecnológicas a empresa transnacional conquista grande liberdade para deslocar as suas atividades e os seus projetos para as localidades mais propícias à pesquisa e desenvolvimento. Com a absorção de conhecimento de outras regiões a ETN pode criar condições para sustentar e estimular o esforço tecnológico nos países centrais.

Concordamos com Gomes (2003) quando enfatiza que estimulando a troca de conhecimento e a (re)combinação de tecnologias internacionalmente, as atividades realizadas pelas subsidiárias no estrangeiro podem originar em fertilização cruzada entre as unidades dispersas geograficamente. 
GALVÃO, C.A. \& PEREIRA, V.F. Empresas transnacionais (ETNs) e os ...

Em concordância com as observações de Gomes (2003) nota-se que as subsidiárias das empresas transnacionais nos países emergentes passaram a ter um papel mais ativo no processo criativo e deixam de ser simples escoadouro da efetiva aplicação de tecnologia de produtos centralmente desenvolvidos. Assim, passam a ter um papel importante na geração de novas tecnologias e produtos.

Concordamos com Rodrik (2011) que atribui um papel destacado ao Estado-nação na tomada de decisões. Quanto à governança global temos que aceitar que é um conceito em construção, ainda que muitos teóricos percebam evidências da emergência de novos modelos de governança global.

Rodrik (2011) apresentou o caso da União Europeia e mostrou que ela é um exemplo potencial para a governança global, uma vez que a integração das nações europeias foi obtida através de artifícios institucionais para remover custos transacionais e criar harmonização nas regulações. $\mathrm{O}$ autor aponta que o dilema da Europa não é diferente do que o que é enfrentado pela economia mundial como um todo e que para aprofundar a integração econômica faz-se necessário erigir uma extensa estrutura de governança transnacional, sendo que as novas formas de governança global se deparam com as identidades políticas e os pertencimentos que ainda giram em torno de Estados-nação.

$\mathrm{O}$ que ficou claro a partir da revisão bibliográfica aqui apresentada é que se torna urgente lutar pela existência de instâncias supranacionais, presentes e fortes, que venham a desempenhar de forma mais efetiva seu papel como reguladoras do avanço das ETNs, atenuando ou revertendo as consequências negativas da expansão do capitalismo global, instituindo uma legislação para uma economia global.

A globalização tem gradualmente reduzido a importância das instituições econômicas em nível do Estado-nação, tais como eram conhecidas no período pós-Segunda Guerra Mundial, assim existe uma demanda urgente por um Estado indutor-normativoregulador, que atue, via leis e instituições, impedindo os abusos das 
GALVÃO, C.A. \& PEREIRA, V.F. Empresas transnacionais (ETNs) e os ...

ETNs. Além disso, deve ser atribuindo um papel ativo à sociedade civil no sentido de regular os abusos de empresas transnacionais.

\section{Referências bibliográficas}

ASCANI, Andrea; CRESCENZI, Riccardo; IAMMARINO, Simona. Regional Economic Development: A Review. WP1/03 SEARCH WORKING PAPER, Department of Geography and Environment, London School of Economics and Political Science.

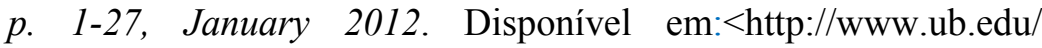
searchproject/wp-content/uploads/2012/02/WP-1.3.pdf>. Acesso em: 18 abr. 2016.

BAAFI, Alex Bossman. Multinational Corporations And The Developing World, GhanaWeb, 15 november, 2009, Disponivel em: <http://www.ghanaweb.com/GhanaHomePage/NewsArchive/ Multinational-Corporations-And-The-Developing-World-171863>. Acesso em: 25 out. 2016.

CORRÊA, Roberto Lobato. Corporaçoes, práticas espaciais e gestão do território. Departamento de Geografia, IGEO/UFRJ. Disponível em: <www.anuario.igeo.ufrj.br/anuario_1992/vol_ 15_35_42.pdf>. Acesso em: 28 set. 2016.

DICKEN, Peter. Mudança global - mapeando as novas fronteiras da economia mundial, Porto Alegre: Bookman, 2010.

DUPAS, Gilberto. Economia global e exclusão social - pobreza, emprego, Estado e o futuro do capitalismo. São Paulo, Paz e Terra, 2001.

FÉRNANDEZ, Maurício Lascurain. As empresas multinacionais e os seus efeitos nos países menos desenvolvidos. Nova Era, $n^{\circ} 36$, janeiro-junho de 2012. p.83-105. 
GALVÃO, C.A. \& PEREIRA, V.F. Empresas transnacionais (ETNs) e os ...

GOMES, Rogério A Internacionalização das atividades tecnológicas pelas empresas transnacionais: elementos de organização industrial da economia da inovação. 2003. $204 f$. Tese (Doutorado) - Universidade Estadual de Campinas, Instituto de Economia, Campinas.

HAESBAERT, Rogério. Da desterritorialização á multiterritorialidade, In: Anais do X Encontro de Geógrafos da América Latina, Universidade de São Paulo, 20 a 26 de março de 2005.

HARVEY, David. A Geografia Disso tudo. In: O Enigma do capital e as crises do capitalismo. São Paulo, Boitempo, 2011.

LIPIETZ, Alain. O Local e o Global: Personalidade Regional ou Inter-regionalidade? Revista Espaço e Debates, Ano XIV, no 38, pp.10-20, 1994.

LIPIETZ, Alain. Os Impasses do Liberal-Produtivismo. In: - Uma Alternativa para o Século 21. São Paulo, Nobel, pp. 57-73, 2002.

MOLLO, Maria de Lourdes Rollemberg Globalização da Economia, Exclusão Social e Instabilidade. Disponível em: $<\mathrm{http}$ ://www.intelecto.net/cidadania/global-4.html>. Acesso em: 15 de junho de 2013.

POCHMANN, Márcio et ali. Globalização e Exclusão Social. In: Atlas da exclusão social Volume 4- A Exclusão no mundo. São Paulo, Cortez, pp. 27-54, 2004.

RODRIK, Dani. Is Global Governance Feasible? Is it desirable? In: Why markets, States, and Democracy Can't Coexist: The Globalization Paradox, Oxford, Great Britain, Oxford University Press, 2011. Cap. 10, p. 207-232. 
GALVÃO, C.A. \& PEREIRA, V.F. Empresas transnacionais (ETNs) e os ... SANTOS, Milton. A natureza do espaço: técnica e tempo, razão, São Paulo, Editora da Universidade de São Paulo, 2006.

STIGLITZ, Joseph E. The Multinational Corporation. In: Making globalization work. 2006, pp. 187-210.

STORPER, Michael Territorialização em uma economia global: possibilidades de desenvolvimento tecnológico, comercial e regional em economias subdesenvolvidas. In: Lavinas et al. (orgs.) Integração, região e regionalismo. Rio de Janeiro: Bertrand Brasil, 1994.

Recebido em novembro de 2016 Aceito em dezembro de 2016 